\title{
NMR metabonomic study of lung cancer: metabolic profiling of tissues
}

\author{
Cláudia M Rocha ${ }^{*}$, António S Barros², Ana M Gil ${ }^{1}$, Brian J Goodfellow ${ }^{1}$, Isabel M Carreira ${ }^{3}$, João Bernardo ${ }^{4}$, \\ Ana Gomes ${ }^{4}$, Vítor Sousa ${ }^{4,5}$, Lina Carvalho ${ }^{4,5}$, lola F Duarte ${ }^{1}$ \\ From 16th International Charles Heidelberger Symposium on Cancer Research \\ Coimbra, Portugal. 26-28 September 2010
}

This work aims to evaluate the potential of ${ }^{1} \mathrm{H}$ Nuclear Magnetic Resonance (NMR) spectroscopy combined with multivariate statistics (metabonomics) for finding malignancy biomarkers in lung tissue and discriminating between different tumour histological types. Paired tissue samples from 32 patients with primary lung cancer were directly analysed by ${ }^{1} \mathrm{H}$ High Resolution Magic Angle Spinning (HRMAS) NMR (500 MHz) and the spectral profiles subjected to Principal Component Analysis (PCA) and Partial Least Squares Regression Discriminant Analysis (PLS-DA). Tumor and control tissues were clearly discriminated in the PLS-DA model with 95\% sensitivity and 100\% specificity. In agreement with previous work [1], the metabolites giving rise to this separation were mainly lactate, glycerophosphocholine, phosphocholine, taurine, glutathione and uridine di/triphosphate (elevated in tumours), and glucose, phosphoethanolamine, acetate, lysine, methionine, glycine, myo- and scyllo-inositol (reduced in tumours compared to control tissues). Regarding differentiation of histological types, carcinoid tumors showed a distinct profile characterized by very low lipid levels, the presence of broad signals possibly arising from oligopeptides, decreased PC/GPC ratio and increased taurine and ascorbate levels. Epidermoid tumors could also be differentiated from adenocarcinomas due to increased lipids, lactate, creatine and GSH and decreased taurine, choline and $\mathrm{PC}$. The biochemical information retrieved, not available by conventional histopathology, may provide additional criteria for improving clinical decisions and potentially aid in the differential diagnosis of lung tumors.

* Correspondence: claudia.rocha@ua.pt

'CICECO, Department of Chemistry, University of Aveiro, Aveiro, Portugal

Full list of author information is available at the end of the article
Author details

'CICECO, Department of Chemistry, University of Aveiro, Aveiro, Portugal. ${ }^{2}$ QOPNA, Department of Chemistry, University of Aveiro, Aveiro, Portugal. ${ }^{3}$ Cytogenetics Laboratory and CNC, Faculty of Medicine, University of Coimbra, Coimbra, Portugal. ${ }^{4}$ University Hospitals of Coimbra, Coimbra, Portugal. ${ }^{5}$ Institute of Pathological Anatomy, Faculty of Medicine, University of Coimbra, Coimbra, Portugal.

Published: 24 September 2010

\section{Reference}

1. Rocha C, Barros AS, Gil AM, Goodfellow BJ, Humpfer E, Spraul M, Carreira IM, Melo JB, Bernardo J, Gomes A, Sousa V, Carvalho L, Duarte IF: Metabolic profiling of human lung cancer tissue by ${ }^{1} \mathrm{H}$ High Resolution Magic Angle Spinning (HRMAS) NMR spectroscopy. J Proteome Res 2010, 9:319-332.

\section{doi:10.1021/pr9006574}

Cite this article as: Rocha et al:: NMR metabonomic study of lung cancer: metabolic profiling of tissues. BMC Proceedings 2010 4(Suppl 2): P66.

Submit your next manuscript to BioMed Central and take full advantage of:

- Convenient online submission

- Thorough peer review

- No space constraints or color figure charges

- Immediate publication on acceptance

- Inclusion in PubMed, CAS, Scopus and Google Scholar

- Research which is freely available for redistribution 